\title{
Comparative microbiological analysis of four different sea fishes collected from local market in Dhaka Metropolis
}

\author{
1, *Nur, I.T., ${ }^{2}$ Mou, A.N. and ${ }^{1}$ Habiba, U. \\ ${ }^{1}$ Department of Microbiology, Stamford University Bangladesh, 51 Siddeswari Road, Dhaka-1217, \\ Bangladesh \\ ${ }^{2}$ Biotechnology and Genetic Engineering Discipline, Khulna University, Khulna 9208, Bangladesh
}

\section{Article history: \\ Received: 14 July 2019 \\ Received in revised form: 5 \\ August 2019 \\ Accepted: 14 August 2019 \\ Available Online: 6 \\ September 2019}

\section{Keywords:}

Raw fish,

Cooked fish,

Frozen cooked fish,

Pathogens,

Microbiological quality

DOI:

https://doi.org/10.26656/fr.2017.4(1).253

\begin{abstract}
The present investigation attempted to evaluate the existence and survival of spoilage microorganisms in four common sea fishes (Poma, Rupchanda, Koral and Tuna) available in Bangladesh and to determine the effects of cooking temperature to optimize the growth of fish microflora. Moreover, the status of fish in frozen condition after cooking was also studied. A total 4 categories of sea fishes were collected from the local shops in Dhaka city. Raw, cooked and frozen fish samples were analyzed for the existence of pathogenic bacteria through the conventional cultural techniques and the confirmative biochemical identification procedures. Total viable bacteria were present in all four fish samples in raw, cooked and frozen condition up to $6 \log \mathrm{CFU} / \mathrm{mL}$. Most of the raw fish samples were found to harbor a huge population of microorganisms up to $5 \log C F U / \mathrm{mL}$ including the fecal coliforms. Several specific bacterial species like E. coli, Klebsiella spp., Salmonella spp., Shigella spp., Staphylococcus spp., Pseudomonas spp. and Vibrio spp. were present in raw samples. However, the microbial load reduced from the fish after cooking and the status was static in frozen condition. Thus, the incidence of fecal coliforms in raw fish may be considered as a serious threat to the public health upon consumption of such fishes.
\end{abstract}

\section{Introduction}

Fish and fish products are important source of animal protein, highly unsaturated fatty acid (HUFA) and polyunsaturated fatty acid (PUFA), minerals and vitamin. Marine fish oil is a good source of omega-3 fatty acids (Huynh et al., 2007; Dhaneesh et al., 2012; Belton et al., 2014). In Bangladesh, about $60 \%$ of the total animal protein intake is obtained from fishery products (Bogarda et al., 2015; Eizenberga et al., 2015). Marine water of Bangladesh also has 442 species of fish and 36species of marine shrimps and which is widely consumed by Bangladeshi people and tourists (Quader, 2010).

Because of its high nutritive value, sea fishes are a major vehicle for pathogenic bacteria. Fishes can be contaminated by both aquatic environment and postharvesting condition (Al-Sheraa, 2018). Due to the attack of pathogenic bacteria and fungi a wide ranges of sea fishes spoilages occurs which adversely affect the economic condition in Bangladesh and as well as public health. Contamination of sea fishes can take places at several stages of transport, handling, processing, packaging and storage condition by both bacteria and fungi. It was reported that Processing materials, water and ice could be a source of contamination (Sanjee and Karim, 2016). However, normal flora of fish proceeds spoilage due to inappropriate packaging (Bryan, 1980; Okonko et al., 2008; Okonko et al., 2009). Aeromonas, Vibrio spp., Pseudomonas spp., Staphylococcus spp., Salmonella spp., Listeria spp., Clostridium perfringens. are mainly caused various foodborne illness when they enter our intestine through contaminated sea fishes (Feldhusen, 2000; Vazquez-sanchez et al, 2012; Zarei et al., 2012; Falaise et al., 2016; Iwamoto et al., 2000). Along with bacteria and fungi, seafood-associated illness occurring by viruses (Norovirus and Hepatitis A) and certain parasites. Most outbreaks of food poisoning associated with fish and seafood derive from the consumption of raw or insufficiently heat treatment, insufficient cooking and cross-contamination during processing (Mohammed et al., 2017).

Raw fishes naturally have a number of bacteria, and this can be opportunistic and causing foodborne infections rapidly if it is left for several hours at room temperature without processing. Pathogenic bacteria 
especially Salmonella spp. and Vibrio spp. are the primary concern of food safety with regard to seafood. When seafood is processed with uncontaminated water and cooked properly, it lowers the tendency the risk of food poisoning. Lack of proper temperature control is significant factors that can lead to pathogen growth and foodborne illness. Frozen fish are prone to contaminated by Listeria spp. (Reij et al., 2004; Jelena et al., 2011). Previously several studies showed that some thermostable enterotoxin of Staphylococcus aureus and Escherichia coli would not destroy completely even after cooking of seafood or if the food cooked properly, due to improper handling recontamination can take place and consumption of this type of food causes severe food poisoning (Ayulo et al., 1994; Vieira et al., 2001; Omeo et al., 2005; Simon and Sanjeev, 2007; Beleneva, 2011; Tango et al., 2015). On the other hand, cooked-frozen fish are widely consumed by working people in their busy life. They cooked fish and kept it in the refrigerator for 3-7 days or more. During this period the shelf-life of fish its organoleptic and chemical properties can be changed. Presence of $S$. aureus and Bacillus cereus was recorded in some cooked-frozen fish and meat as they are able to grow at refrigeration temperatures though a lower growth rate (Nyati, 2000; Rybka et al., 2011; Shakila et al., 2011). Along this line, it was clear that microbes can be found in any of the three conditions. So, the aim of our present studies is to determine the comparative microbiological quality among raw, cooked and cooked-frozen fish.

\section{Materials and methods}

\subsection{Study area and sample collection}

For the analysis of microbial load, Four fish samples (Rupchada, Koral,Tuna, Poma) were collected from the local market in Dhaka city using a sterile aseptic container together with ice. A total of $20 \mathrm{~g}$ of raw, cooked and cooked frozen sample of each fish was homogenized with $180 \mathrm{~g}$ of sterile normal saline. The homogenized suspension was subjected to serial dilutions (10-fold) up to $10^{6}$ with normal saline (APHA 1998).

\subsection{Enumeration of total viable bacteria and fungus}

For enumerating total viable bacteria (TVB) and total fungal count, $0.1 \mathrm{~mL}$ of each sample was spread onto Nutrient agar (NA) and Sabouraud dextrose agar (SDA) respectively. For TVB, plates were incubated at $37^{\circ} \mathrm{C}$. For fungal assay, plates were incubated at $25^{\circ} \mathrm{C}$ for 3 days (Sharmin et al., 2014).

\subsection{Isolation of total coliform and fecal coliform}

For the isolation of coliforms and fecal $0.1 \mathrm{~mL}$ suspension was spread over MacConkey agar and $\mathrm{mFC}$ agar. For the isolation of E. coli and Klebsiella spp., plates were incubated at $37^{\circ} \mathrm{C}$ for $18-24 \mathrm{hrs}$. The presence of $E$. coli was further confirmed by the appearance of bluish-black colonies with green metallic sheen on eosin-methylene blue (EMB) agar. While for fecal coliforms, plates were incubated at $44.5^{\circ} \mathrm{C}$ for 24 hrs (Sharmin et al., 2014).

\subsection{Assay of pathogenic bacterial load}

For the isolation of Salmonella spp., Shigella spp., Vibrio spp. and Staphylococcus spp., $0.1 \mathrm{~mL}$ of suspension was spread onto Xylose Lysine Deoxycholate (XLD), Thiosulphate Citrate Bile Salt Sucrose (TCBS) agar plates and Mannitol salt agar (MSA) respectively. After incubation at $37^{\circ} \mathrm{C}$ for $24 \mathrm{hrs}$, characteristic colonies were enumerated (Sharmin et al., 2014).

\section{Results and discussion}

The spoilage of sea fish caused by different bacteria is not very infrequent. Therefore, it is very essential to ensure the quality of fish as well as the consumer's safety. In our previous study, we were able to identify a huge array of microbial growth in different sea fish samples of which most were drug-resistant (Noor et al., 2013). In the current study, higher pathogenic loads were found in all the category of four sea fish samples employed and all the isolates were biochemically identified (Table 1). The bacterial contamination was very high in raw fish samples rather than the cooked and frozen fish. The total viable bacteria and fungal growth were found in raw fish poma fish nearly $7 \log \mathrm{CFU} / \mathrm{mL}$. Total viable bacteria were also present in cooked and frozen poma fish up to $6 \log$ and $4.5 \log \mathrm{CFU} / \mathrm{mL}$ respectively. In case of specific pathogens like E. coli, Klebsiella, Staphylococcus spp., Shigella spp., Salmonella spp., Pseudomonas spp. and Vibrio spp. were present within the range of $2.5-4.0 \log \mathrm{CFU} / \mathrm{mL}$. Frozen poma fish was totally contamination-free in case of all pathogens but E. coli and Pseudomonas spp. was present in cooked poma fish. Both raw and cooked poma fish were found to be fecally contaminated (Figure 1A). In the case of rupchanda fish, raw, cooked and frozen state was found to be contaminated by viable bacteria up to $5.5 \log \mathrm{CFU} / \mathrm{mL}$. The specific pathogens were noticed in raw rupchanda fish up to $5 \log \mathrm{CFU} / \mathrm{mL}$ whereas $E$. coli and Staphylococcus spp. were present in frozen rupchanda within the range of $2.2-3.5 \log \mathrm{CFU} / \mathrm{mL}$. The growth of Shigella spp. was absent in all 3 categories of rupchanda fish. Raw rupchanda fish showed the existence of fecal bacteria (Figure 1B). 
Table 1. Biochemical identification of the bacterial isolates from sea fish.

\begin{tabular}{|c|c|c|c|c|c|c|c|c|c|c|c|}
\hline \multirow{2}{*}{$\begin{array}{l}\text { Assumed Pathogenic } \\
\text { Microorganisms }\end{array}$} & \multicolumn{4}{|c|}{ TSI } & \multirow{2}{*}{ Motility } & \multirow{2}{*}{$\begin{array}{c}\text { Indole } \\
\text { Production }\end{array}$} & \multirow{2}{*}{ MR } & \multirow{2}{*}{ VP } & \multirow{2}{*}{$\begin{array}{l}\text { Citrate } \\
\text { utilization }\end{array}$} & \multirow[b]{2}{*}{ Catalase } & \multirow[b]{2}{*}{ Oxidase } \\
\hline & Slant & Butt & Gas & $\mathrm{H}_{2} \mathrm{~S}$ & & & & & & & \\
\hline E. coli & $\mathrm{Y}$ & $\mathrm{Y}$ & + & - & + & + & + & - & - & + & - \\
\hline Klebsiella spp. & $\mathrm{Y}$ & $\mathrm{Y}$ & + & - & + & - & - & - & + & + & - \\
\hline Vibrio spp. & $\mathrm{R}$ & $\mathrm{Y}$ & - & - & + & - & + & - & - & + & + \\
\hline Staphylococcus spp. & $\mathrm{Y}$ & $\mathrm{Y}$ & - & - & + & - & + & - & - & + & - \\
\hline Pseudomonas spp. & $\mathrm{R}$ & $\mathrm{Y}$ & - & - & + & - & + & - & - & + & + \\
\hline Salmonella spp. & $\mathrm{R}$ & $\mathrm{Y}$ & - & - & + & - & + & - & - & - & - \\
\hline Shigella spp. & $\mathrm{R}$ & $\mathrm{Y}$ & + & - & - & $+/-$ & + & - & - & - & - \\
\hline
\end{tabular}

All the experiments have been done three times and the results were reproducible. One representative data have been shown. TSI: Triple Sugar Iron Test; Y: Yellow (Acid); R: Red (Alkaline); MR: Methyl red and; VP: Voges-Proskauer
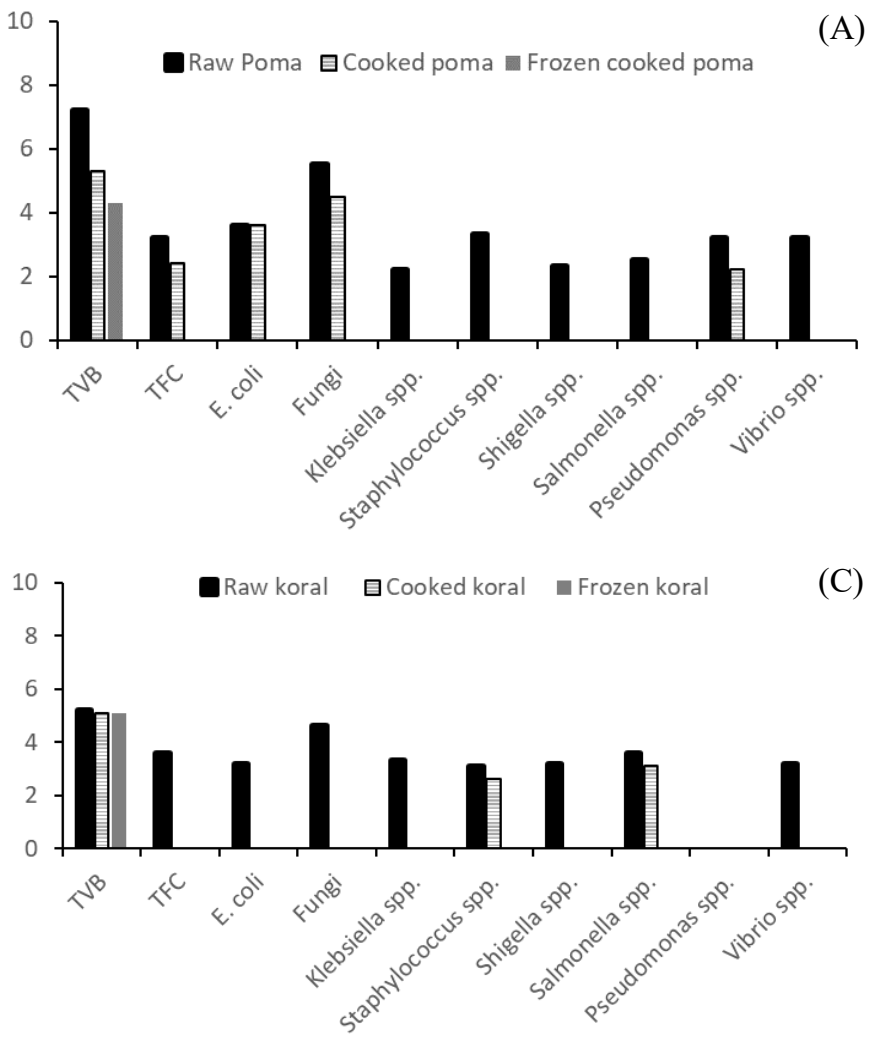

Figure 1. Microbiological status of different sea fish: poma fish (A); rupchanda fish (B); koral fish (C); and tuna fish (D).

Meanwhile, the raw koral fish exhibited the huge array of E. coli, Klebsiella spp., Staphylococcus spp., Shigella spp., Salmonella spp., Pseudomonas spp. and Vibrio spp. up to $4 \log \mathrm{CFU} / \mathrm{mL}$. Only Staphylococcus spp. and Salmonella spp. were present in cooked koral samples up to $3.7 \log \mathrm{CFU} / \mathrm{mL}$. All three categories exhibited total viable bacteria. Only raw koral fish had fungal load (Figure 1C).

The raw tuna fish showed huge fungal contamination as well as total viable bacteria which was recorded within the range of 5.5 to $6 \log \mathrm{CFU} / \mathrm{mL}$ (Figure 1D). In case of specific bacteria, E. coli, Staphylococcus spp., Shigella spp., Salmonella spp. and Vibrio spp. was present in raw tuna fish up to $4.5 \log \mathrm{CFU} / \mathrm{mL}$ while Pseudomonas spp. was absent in raw, cooked and frozen tuna. Staphylococcus spp. was present in raw, cooked and frozen samples within the range of $2.7 \log$ to $4.3 \log$

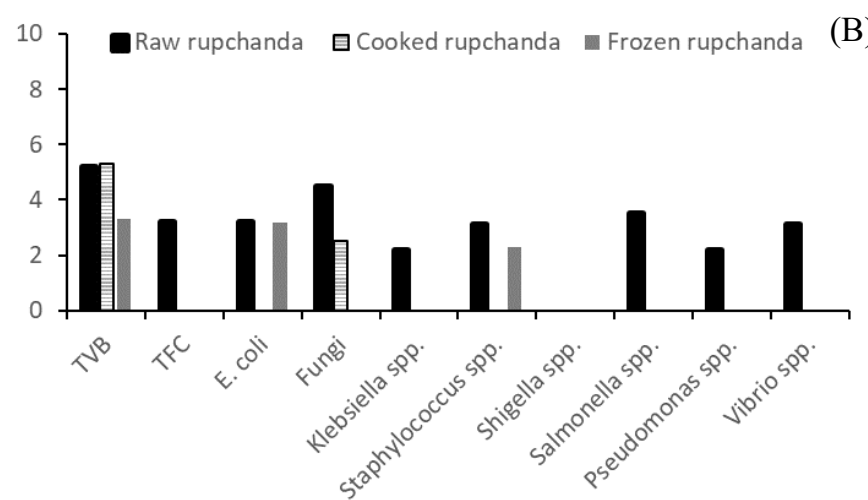

(B)

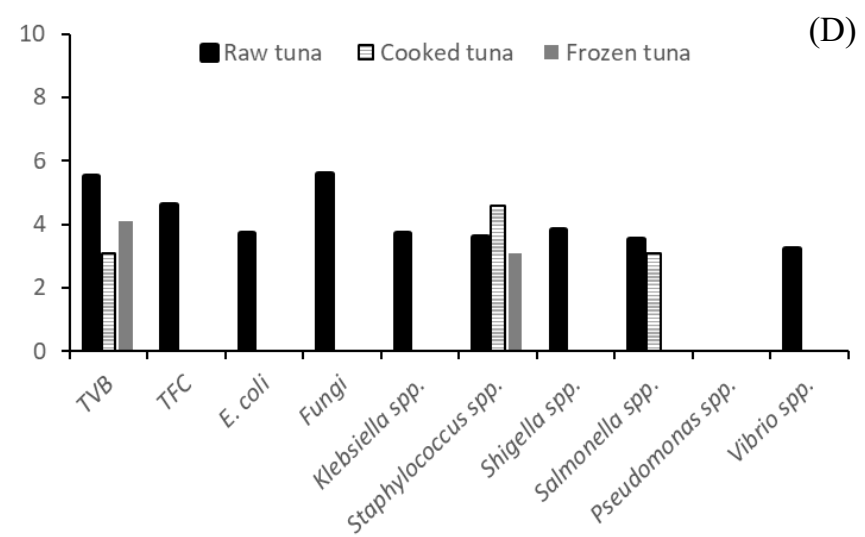

$\mathrm{CFU} / \mathrm{mL}$ (Figure 1D). Only the raw tuna showed fecal contamination.

As described in our early study, several factors may affect the overall quality of the food and fish such as contaminated ice, transportation and poor storage condition or due to cross-contamination from other fish (Noor et al., 2013).

\section{Conclusion}

The results of the current study confirmed the existence of contaminating microorganisms in sea fish especially in raw samples. In the current study, the cooked and frozen samples were quite satisfactory rather than the raw samples. This study tried to sort out the cooking effects on the reduction of existence microorganism in the fish samples as well as the various 
consequences may happen during the frozen condition. The bacterial load was remarkably reduced after cooking and even the quality was sustained in the frozen state. In the future, it would be important to evaluate the drug resistance traits of the fish microflora to ensure the consumer's health. However, the major outcome of this very study is the cooking effects in proper temperature may reduce the microbial spoilage in food and fish.

\section{References}

Al-sheraa, A.S. (2018). Microbial quality of three imported fresh locally produced marine fishes in alfaw city, Basrah, Iraq. Journal of Aquaculture Research and Development, 9, $4 \mathrm{https://}$ doi.org/10.4172/2155-9546.1000531

Ayulo, A.M., Machado, R.A., Scussel, V.M. (1994). Enterotoxigenic Escherichia coli and Staphylococcus aureus in fish and seafood from the southern region of Brazil. International Journal of Food Microbiology, 24(1-2), 171-178. https:// doi.org/10.1016/0168-1605(94)90116-3

Beleneva, I.A. (2011). Incidence and characteristics of Staphylococcus aureus and Listeria monocytogenes from the Japan and South China seas. Marine Pollution Bulletin, 62(1), 382-387. https:// doi.org/10.1016/j.marpolbul.2010.09.024

Belton, B., van Asseldonk, I.J.M., Thilsted S.H. (2014). Faltering fisheries and ascendant aquaculture: implications for food and nutrition security in Bangladesh. Food Policy, 44, 77-87. https:// doi.org/10.1016/j.foodpol.2013.11.003

Bogarda J.R, Thilsted, S.H., Marks, G.C., Wahab, M.A., Hossain, M.A.R., Jakobsen, J., Stangoulis, J. (2015). Nutrient composition of important fish species in Bangladesh and potential contribution to recommended nutrient intakes. Journal of Food Composition and Analysis, 42, 120-133. https:// doi.org/10.1016/j.jfca.2015.03.002

Bryan, F.L. (1980). Epidemiology of food borne diseases transmitted by fish, shellfish and marine crustaceans in the United States 1970-1978. Journal of Food Protection, 43(11), 859-876. https:// doi.org/10.4315/0362-028X-43.11.859

Dhaneesh, K.V., Noushad, K.M., Kumar, T.T.A. (2012). Nutritional evaluation of commercially important fish species of Lakshadweep Archipelago, India. PLoS One, 7(9), e45439. https://doi.org/10.1371/ journal.pone.0045439

Eizenberga, I., Terentjeva, M., Valcin, O., Novoslavskij, A., Strazdiņa, V., Ošmjana, J., Bērziņs A. (2015). Microbiological quality of raw fish at retail market in Latvia. "Nordic View to Sustainable Rural
Development", Proceedings of the $25^{\text {th }}$ NJF Congress, Riga, Latvia, 16-18 June 2015, p. 324328. Riga, Latvia: Latvia University of Agriculture.

Falaise, C., François, C., Travers, M.A., Morga, B., Haure, J., Tremblay, R., Turcotte, F., Pasetto, P., Gastineau, R., Hardivillier, Y., Leignel, V., Mouget, J.L. (2016). Antimicrobial compounds from eukaryotic microalgae against human pathogens and diseases in aquaculture. Marine Drugs, 14(9), 159. https://doi.org/10.3390/ md14090159

Feldhusen, F. (2000). The role of seafood in bacterial foodborne diseases. Microbes and Infection, 2(13), 1651-1660. https://doi.org/10.1016/S1286-4579(00) 01321-6

Huynh, M.D., Kitts, D.D., Hu, C., Trites, A.W. (2007). Comparison of fatty acid profiles of spawning and non-spawning Pacific herring, Clupeaharengus pallasi. Comparative Biochemistry and Physiology Part B: Biochemistry and Molecular Biology, 146 (4), 504-511. https://doi.org/10.1016/ j.cbpb.2006.11.023

Iwamoto, M., Ayers, T., Mahon, B.E. and Swerdlow, D.L. (2010). Epidemiology of seafood-associated infections in the United States. Clinical Microbiology Reviews, 23(2), 399-411. https:// doi.org/10.1128/CMR.00059-09

Jelena, K., Ruzica, A., Baltic, M., Misic, D., Mirjana, D., Marija, S., Asanin, N. and Kovacevic, I.K. (2011). Presence of Listeria spp. in fish samples, fish products and sea products. Acta Veterinaria (Beograd), 61(2-3), 193-203. https://doi.org/10.2298/ AVB1103193K

Mohammed, A.E., Abdallah, H.A., Abd El-Hafez, A.E.M., Amin, A. and Mousa, M.M. (2017). Quality Assessment of Some Retailed Marine Fish and Shellfish in Alexandria Province. Alexandria Journal of Veterinary Sciences, 52(1), 166-172. https://doi.org/10.5455/ajvs.233057

Noor, R., Acharjee, M., Ahmed, T., Das, K.K., Paul, L., Munshi, S.K., Urmi, N.J., Rahman, F., Alam, M.Z. (2013). Microbiological study of major sea fish available in local markets of Dhaka city, Bangladesh. Journal of Microbiology Biotechnology and Food Sciences, 2(4), 2420-2430

Nyati, H. (2000). An evaluation of the effect of storage and processing temperatures on the microbial status of sous vide extended shelf life products. Food Control, 11(6), 471-476. https://doi.org/10.1016/ S0956-7135(00)00013-X

Okonko, I.O., Ogun, A.A., Adejoye, O.D., Ogunjobi, A.A., Nkang, A.O., Adebayo-Tayo, B.C. (2009). 
Hazards analysis critical control points (HACCP) and Microbiology qualities of Seafoods as affected by Handler's Hygiene in Ibadan and Lagos, Nigeria. African Journal of Food Sciences, 3(1), 35-50

Okonko, I.O., Ogunjobi, A.A., Fajobi, E.A., Onaja, B.A., Babalola, E.T., Adedeji, A.O. (2008). Comparative Studies and Different Assessment of Ready-to-Eat (RTE) Frozen Sea Foods Processed in Ijola-Olopa Lagos State, Nigeria. African Journal of Biotechnology, 7(16), 2898 - 2901.

Omoe, K., Dong-Liang, H., Takahashi-Omoe, H., Nakane, A., Shinagawa, K. (2005) Comprehensive analysis of classical and newly described staphylococcal super antigenic 17 toxin genes in Staphylococcus aureus isolates. FEMS Microbiology Letters, 246(2), 191-198. https://doi.org/10.1016/ j.femsle.2005.04.007

Quader, O. (2010). Coastal and marine biodiversity of Bangladesh (Bay of Bengal). Proceedings of International Conference on Environmental Aspects of Bangladesh (ICEAB 10) September 4, 2010, p. 83 -86. Japan: Bangladesh Environment Network Japan chapter

Reij, M.W. and Den Aantrekker, E.D., ILSI Europe Risk Analysis in Microbiology Task Force. (2004). Recontamination as a source of pathogens in processed foods. International Journal of Food Microbiology, 91(1), 1-11. https://doi.org/10.1016/ S0168-1605(03)00295-2

Rybka, S., Kailasapathy, K., Bergan, J., Poniman, S., Mikhail, S., Gunasekara, C., Lin, Y., Ferraris, J. (2011). Storage characteristics of extended shelf life cook-chill meals. Food Australia, 53(5), 191-195.

Sanjee, S.A. and Karim, M.E. (2016). Microbiological Quality Assessment of Frozen Fish and Fish Processing Materials from Bangladesh. International Journal of Food Science, 2016, 1-6.https:// doi.org/10.1155/2016/8605689

Shakila, R.J, Raj, B.E. and Felix, N. (2011). Quality and safety of fish curry processed by sous vide cook chilled and hot filled technology process during refrigerated storage. Food Science and Technology International, 18(3), 261-269. https:// doi.org/10.1177/1082013211415177

Sharmin, M., Nur, I.T., Acharjee, M., Munshi, S.K. and Noor, R. (2014). Microbiological profiling and the demonstration of in vitro anti-bacterial traits of the major oral herbal medicines used in Dhaka Metropolis. SpringerPlus, 3, 739. https:// doi.org/10.1186/2193-1801-3-739

Simon, S.S. and Sanjeev, S. (2007). Prevalence of enterotoxigenic Staphylococcus aureus in fishery products and fish processing factory workers. Food Control, 18(12),1565- 1568. https://doi.org/10.1016/ j.foodcont.2006.12.007

Tango, C.N, Hong, S.S., Wang, J. and Oh, D.H., (2015). Assessment of enterotoxin production and crosscontamination of Staphylococcus aureus between food processing materials and Ready-To-Eat cooked fish paste. Journal of Food Science, 80(12), 29112916. https://doi.org/10.1111/1750-3841.13143

Vazquez-sanchez, D., Lopez-cabo, M., Saa-Ibusquiz, P. and Rodriguez-herrera, J.J. (2012). Incidence and characterization of Staphylococcus aureus in fishery products marketed in Galicia (Northwest Spain). International Journal of Food Microbiology, 157(2), 286-296.

j.ijfoodmicro.2012.05.021

Vieira, R.H.S.F., Rodrigues, D.P., Gocalves, F.A., Menezes, F.G.R., Aragao, J.S. and Sousa, O.V. (2001). Microbicidal effect of medicinal plant extracts (Psidiumguajava Linn. and Carica papaya Linn.) upon bacteria isolated from fish muscle and known to induce diarrhea in children. Revista do Instituto de Medicina Tropical de São Paulo, 43(1), 145-148. $\quad$ https://doi.org/10.1590/S003646652001000300005

Zarei, M., Maktabi, S. and Ghorbanpour, M. (2012). Prevalence of Listeria monocytogenes, Vibrio parahaemolyticus, Staphylococcus aureus, and Salmonella spp. in seafood products using multiplex polymerase chain reaction. Foodborne Pathogens and Disease, 9(2), 108-112. https://doi.org/10.1089/ fpd.2011.0989 